\title{
Public Higher Education Governing Boards Composition and Regional Difference in U.S.
}

\section{Park, Hyun Ju ; Zhu, Qiong}

The Pennsylvania State University, U.S.A., Department of Educational Policy Studies

\begin{abstract}
Using The Public Higher Education Boards Database designed by Association of Governing Boards of Universities and Colleges (AGB) in 2008, this paper reviewed prior studies of governing boards and investigated regional differences in boards' characteristics including board type, selection method, board composition, provision condition, term length, supervision and meeting frequency. The results show that: (1) highly centralized state university governance with more political control exist in West and Middle West; (2) governing boards in Northeast are more autonomous with high percentage of alumni and self-perpetuating members, and less political affiliations; (3) more faculty participation appear in South and West and most Middle West boards do not have removal process and longer length of term.
\end{abstract}

Keywords: public, governing board, regional difference 


\section{Introduction}

Neither the complete autonomy of universities from the state government nor sheer accountability of the institutions to the state does not exist in the U.S. higher education sector. The dual demands of obtaining autonomy and meeting requirements of accountability cause tension when the state and the university regulate affairs occurring in the sector. During the twentieth century, the prevailing pattern of the American campusstate relationship was the increasing intervention by state governments (McLendon, 2003). The fundamental shift of decision-making authority in the 1950s and the 1960s was accelerated by "the continued consolidation of campus governance and increasingly powerful statewide coordinating boards" (McLendon, 2003, p.69) This centralized campus governance is implemented by the consolidated governing boards, which represent the most powerful form of campus governance.

Governing boards have important responsibilities in following five domains: ensuring outstanding leadership, articulating the institution's mission, maintaining financial solvency, external relations, and self-assessment (Hendrickson \& Lane, 2013). Recently Association of Governing Boards of Universities and Colleges (AGB) claimed that governing boards are not translating public concerns about higher education into action in the boardroom and the current gap between the society and higher education's governing board members is getting greater (AGB, 2012). This failure of governing board's governance, in fact, originated in its nature - members of governing boards sometimes do not hold expertise which is required to execute legal responsibility over an organization and they do not apprehend campus power structure and do not involve in management decisions, which are essential (Hendrickson \& Lane, 2013). Some great efforts, which have been conducted to investigate the organization of boards and the behavior of trustees, include the selection of trustees, board compositions, trustee cooperation, committee structure, relationship with president, and the effectiveness of boards (AGB, 2009, 2010, 2012; Calhoun \& Kamerchen, 2010; Knott \& Payne, 2001; Minor, 2008; Nason, 1982). However, many of these efforts did not reflect regional differences thoroughly, thereby losing the important ground of college governance study. As institutions in the same region have shared same historical context, demographic changes, resources, and political impacts, governing board's operating system can have some distinctive characteristics based on their region. This paper will describe the characteristics of governing board based on recent data, and further contribute to current research by detecting a regional difference of boards characteristics as an exploratory way.

\section{Literature review}

A considerable body of studies have described the mechanism of governing boards and recommended what an effective board should be since the 1970s. AGB governing board survey revealed, in 2010, the average number of the voting board is about 11 or 12 . Male trustees outnumbered two times than women. 23.1 percent of board members were underrepresented racial and ethnic minorities (4.1 of percent Hispanics and Latinos, 15.8 
percent of African Americans or Blacks, 0.7 percent of American Indians and Alaskan Natives, 2.1 percent of Asians and Pacific Islanders, and 0.4 percent of other races) while 74.3 percents were White non-Hispanic, and 2.6 percents were unknown races. Most trustees (69 \%)'s ages were around 50-69 years old. Half (49.4\%) of board members of public institutions was business, including 24.1 percents of professional service (such as an accountant, attorney/law) and 15.5 percents of education (AGB, 2010). Compared with the survey also conducted by AGB in 1976, female (15\% in 1976) and minority (14\% in 1976) members increased a lot (cited in Nason, 1982). Nevertheless, the current composition of governing board hasn't overthrown the prevalent criticism that people who are white, Anglo-Saxon, Protestant, male, over age 50, coming from business dominate the governing boards (Nason, 1982). The Recent development of studies on governing board is concerned with the structure of governing boards. Several states reformed their higher education governance structure by building a statewide governing board. Although few studies directly investigated how the governing board's behaviors affect institutional performance, an increasing number of empirical studies tested the impact of higher education governance structure on college tuition, state appropriation, and institutional resource allocation. Knott $\&$ Payne (2001) found that universities with a statewide board and with members that are not primarily appointed by the governor had higher productivity and resources. Lowry (2001) demonstrated that public universities in states with statewide coordinating boards or few governing boards, and universities governed by trustees selected by state officials charge much lower tuitions than universities in states of decentralized structures, or governed by trustees chosen by the academic constituents. Calhoun \& Kamerschen (2010) took a further step of tuition analysis. Instead of absolute tuition level, they focused on price discrimination, showing that the ratio of out-of-state to in-state tuition was highest among those universities with the most centralized governance structures.

Given this influential role of governing board's composition and structure, the present study explores differences of the public governing board by region (West, Middle West, Northeast, and South) so that we can offer comprehensive outlook and concrete explanation on the regional difference in U.S. college's public governing board system.

\section{Data}

In this study, we used The Public Higher Education Boards Database designed by AGB in 2008. The database currently contains information on each public higher education coordinating boards and governing boards in all U.S. states. The database is a comprehensive and up-to-date source on the composition, structure, and appointment methods of public governing boards. The only 4-year public governing board were included in the analysis because the database only has a limited number of two- year institutional governing boards. Also, we categorize four regions (West, Middle West, Northeast, and South) based on the Census Bureau Regions and Divisions with State FIPS Codes. The organization of the analysis is as follows. Firstly, we described the state governance 
structure of public 4-year colleges and universities to get a big picture of different types of governing boards. Secondly, we examined the national trend and regional difference of the trustees' selection methods. Lastly, we compared compositions and trustee restrictions of governing boards in different regions. To analyze differences among regions, we conducted Analysis of Variance (ANOVA) for mean comparison of different regions. When a significant difference exists, we additionally explore the differences among means by conducting post hoc test which provides specific information on which regions means are significantly different from each other.

\section{Results and Discussion}

\subsection{Governing Board Type and State Governance Structure}

To describe the state governance structure of public four-year colleges and universities, we categorized states into six categories according to the degree of centralization: comprehensive state governing system (18\%), statewide university governing system (14\%), university governing system without statewide governing boards (18\%), institutional governing boards only (23\%), and the combination of university governing system and institutional governing boards (14\%). West and Midwest have the most centralized governance as eight of all the nine comprehensive state governance systems are implemented in there, such as Utah, Kansas, and North Dakota.

\subsection{Governing Board Selection Methods}

Compared with West and Middle West, public governing boards in Northeast and South averagely have a larger size and fewer members appointed by the governor. Governing boards in South have more members appointed or elected by the legislature than other three regions. West and Middle West governing boards are characterized as 5\% general public election despite Northeast and South barely have a general public election. Northeast have the highest percentage of alumni association appointed members and self-perpetuating members. (See Appendix. Table 1)

\subsection{Governing Board Composition}

As Table 2 shows (See Appendix), 70\% of public governing boards have student board members and only $16 \%$ having faculty members. $4 \%$ of presidents are also the voting members of governing board and $10 \%$ presidents are non-voting members. $12 \%$ of governing boards have the governors as ex officio voting members, and only $2 \%$ are nonvoting members. Comparing different regions, we found that over $80 \%$ of governing boards in West and Northeast have student members while only 56\%-67\% of governing boards in South and Middle West have student members. South has a much high percentage of governing boards with faculty members. Middle West and Northeast have more than 29\% public governing boards whose presidents are also governing board members, mostly non- 
voting members, although less than 11 percent of governing boards in West and South have such presidents. Middle West has a significant fewer governors being ex officio numbers despite voting or nonvoting.

\subsection{Governing Board Trustee restriction}

The trustee restriction is composed of four parts: political affiliation; region and state residence requirement in provision; and requirement of alumni inclusion. Compared with Northeast and South (Table 3, 5, and 6 in Appendix), West and Middle West have low possibility of political affiliation because they limit the number of members with any one political affiliation. In Northeast, governing boards can have relatively high political affiliation possibility. Most members don't have to be affiliated with governments. In the region and state residence requirement, Northeast seems to have distinctively low mean in the restriction of political affiliation and high mean in the region alumni requirement rate.

\subsection{Governing Board Term and Remove Process}

Table 4 presents three aspects of the term of trustees, including term length, term limit, and removal process. In terms of length, three regions have a similar term length of board members: West(5.33), Northeast(5.40), and South(5.48), while mid-West has a quite long term length(6.68) which is also supported by the post hoc test. In the case of term limit, governing boards in South have higher term limits contrasting to West. In the case of term removal process, Middle West presents significantly low mean when comparing to other three regions. It suggests that many governing boards in Middle West have no removal process (see Table 4, 7, and 8 in Appendix). Overall, Middle West region is salient in that it has a longer period and less removal process frequency in its boards.

\section{Conclusion and Discussion}

Using The Public Higher Education Boards Database designed by Association of Governing Boards of Universities and Colleges (AGB) in 2008, this paper investigated regional differences in boards' characteristics including board type, selection method, board composition, provision condition, term length. Three significant regional characteristics stand out. First, highly centralized state university governance with more political control differentiates West and Middle West from other regions. Eight of all the nine comprehensive state governance systems are implemented in West and Midwest, such as Utah, Kansas, and North Dakota. Besides, over 80 percent of trustees in West and Midwest are appointed gubernatorially, while the governor appoints only about 60 percent of trustees in other regions. Four states (Colorado, Michigan, Nebraska and Nevada) in West and Middle West have general public elections, while only one in other regions. Lowry (2001) showed that tuition pricing in states with "centralized" higher education governance is lower than "decentralized" states because "centralized" governance have more influence over university due to the political control of board membership. On the other hand, the 
higher education system in these states is more relying on the state economic and societal situations. Comparing state appropriations among regions, after 2008 economic meltdown, states in West and Middle West decreased state appropriations more rapidly than other states did.

Second, Northeast, on the contrary, have more autonomous governing boards because of less centralized state governance structure, a higher percentage of alumni and selfperpetuating members, and more requirements on alumni participation rather than political affiliation. This institutional autonomy can be partially explained by the tradition of less governmental intervention in higher education and a significant number of elite alumni. Autonomous governing boards tend to understand the institutional situations better and make a decision based on institutional interests. Alumni impact is crucial to colleges and universities because formal and informal interconnections provided by graduates can make possible for institutions to have better chance to negotiate with the legislature, governor's office, foundations and corporations (Weerts \& Ronca, 2007). In the challenging environment, Northeast governing boards are more flexible in facilitating alumni connection and enlarge the possibility of participation of members with political affiliation to adapt to political and financial changes (Weerts \& Ronca, 2007).

Finally, the majority of governing boards have student members while faculty participation varies largely across regions with South and West having the highest participation rate. Although students are still considered as unprepared for trusteeship responsibilities, 70 percent of governing boards are willing to have one or two students; half of them are non-voting members. Including faculty members in governing boards is much more controversial. Some faculty members argue that they should sit on the board and point to the British pattern of faculty control. Governing boards, however, emphasize the inherent and inescapable conflict of interest because trustees must decide what is in the best interest of the institution as a whole, and faculty prerogatives (e.g. rank, salary, leaves, teaching loads, research). Besides, if considering conflicts of interest inside the faculty, the situation could be more dangerous and complex.

Historically, colleges and universities augmented with diverse purposes of the local community, denominational needs, and specific national policies. As Kerr \& Gade(1989) notes, the provincial college was erected by a combination of government, church and lay people with personal fund raising and each institution and state has its history. Governing boards in many regions have developed in a different way and changed over time. However, colleges and universities in the same region share a similar experience in early history, and they prospered while depending on same resources and policy environment of their region.

We assumed that each four region might have different traits in their governing board operating ways. We tried to delineate overall traits of the U.S. universities' public governing board and to find out differences among them, however, there are limitations in our analysis. Including various kinds of representative on a board does not ensure good 
communication and performance of governance. We could not find certain differences in board's type and trustee restriction. Given the performance of governing board is affected by many other reasons, we need to examine further by using the comprehensive method in the future.

\section{References}

AGB. (2009). The leadership dynamic in public colleges and universities system. Washington, DC: Association of Governing Board of Universities and Colleges.

AGB. (2010). Policies, practices, and composition of governing boards of Public colleges, universities, and systems. Washington, DC: Association of Governing Board of Universities and Colleges.

AGB. (2011). The 2011 AGB Survey of Higher Education Governance. Washington, DC: Association of Governing Board of Universities and Colleges.

AGB. (2012). The 2012 AGB Survey of Higher Education Governance College Prices, Costs, and Outcomes Who's Minding the Gap Between Higher Education and the Public. Washington, DC: Association of Governing Board of Universities and Colleges.

Astin, A. (1985). Achieving Educational Excellence. San Francisco: Jossey-Bass.

Calhoun, J., \& Kamerschen, D. (2010). The impact of governing structure on the pricing behavior and market structure of public institutions of higher education in the U.S. International Review of Economics, 57(3), 317-333. doi:10.1007/s12232-010-0089-2.

Hendrickson, R.M. \& Lane, J.E. (2013). Academic leadership and governance of higher education. Sterling, VA: Stylus Publishing.

Kerr, D., \& Gade, M. (1989). The guardians: boards of trustees of American colleges and universities. Washington, DC: Association of Governing Boards.

Knott, J. H., \& Payne, A. A. (2001). The impact of state governance structures on higher education resources and research activity.

Lowry, R. C. (2001). Governmental structure, trustee selection, and public university prices and spending: Multiple means to similar ends. American Journal of Political Science, 845-861.

Minor, J. T. (2008). The Relationship Between Selection Processes of Public Trustees and State Higher Education Performance. Educational Policy, 22(6), 830-853.

Nason, J.W. (1982). The nature of trusteeship: The role and responsibilities of college and university boards.Washington, DC: Association of Governing Boards.

Weerts, D. J., \& Ronca, J. M. (2007). Characteristics of Alumni Donors Who Volunteer at their Alma Mater. Research in Higher Education, 49(3), 274-292. doi:10.1007/s11162007-9077-0 


\section{Appendix}

Table 1. Governing Board Selection Method

\begin{tabular}{cccccccc}
\hline \multirow{2}{*}{ Region } & $\begin{array}{c}\text { Average } \\
\text { size }\end{array}$ & $\begin{array}{c}\text { Guberna- } \\
\text { torially }\end{array}$ & Legislatively & $\begin{array}{c}\text { General } \\
\text { Election }\end{array}$ & Alumni & $\begin{array}{c}\text { Self- } \\
\text { perpetuating }\end{array}$ & Others \\
\hline West & 11 & 80 & 0 & 5 & 0 & 0 & 7 \\
Middle & 10 & 84 & 2 & 5 & 1 & 0 & 4 \\
West & 16 & 66 & 5 & 0 & 3 & 11 & 7 \\
Northeast & 14 & 64 & 10 & 0 & 0 & 3 & 16 \\
South & 14 & 70 & 6 & 2 & 1 & 4 & 10 \\
Total & 13 & & & & & &
\end{tabular}

Table 2. Governing Board Composition by Region

\begin{tabular}{lcccccc}
\hline Region & \multicolumn{6}{c}{ Percentage of Governing Boards having: } \\
\cline { 2 - 6 } & Student & Faculty & $\begin{array}{c}\text { President } \\
\text {-voting }\end{array}$ & $\begin{array}{c}\text { President- } \\
\text { nonvoting }\end{array}$ & $\begin{array}{c}\text { Governor } \\
\text { ex officio- } \\
\text { voting }\end{array}$ & $\begin{array}{c}\text { Governor } \\
\text { ex officio- } \\
\text { nonvoting }\end{array}$ \\
\hline West $(\mathrm{N}=46)$ & 87 & 26 & 7 & 4 & 7 & 4 \\
Middle west $(\mathrm{N}=66)$ & 67 & 0 & 2 & 21 & 2 & 0 \\
Northeast $(\mathrm{N}=55)$ & 89 & 4 & 9 & 20 & 13 & 7 \\
South $(\mathrm{N}=126)$ & 56 & 27 & 2 & 1 & 19 & 0 \\
Total $(\mathrm{N}=293)$ & 70 & 16 & 4 & 10 & 12 & 2 \\
\hline
\end{tabular}

Notes: In the original dataset, the composition of a governing board is set of dichotomous variables indicating whether a governing board has members in a certain category.

Table 3. Descriptive Information of Trustee Restriction

\begin{tabular}{lccc}
\hline Region & \multicolumn{3}{c}{ Percentage of Governing Boards having trustee restrictions in: } \\
\cline { 2 - 4 } & Political affiliation & Region/State Residence & Alumni \\
\hline West $(\mathrm{N}=46)$ & 41 & 24 & 2 \\
Middle West $(\mathrm{N}=66)$ & 36 & 47 & 8 \\
Northeast $(\mathrm{N}=55)$ & 2 & 9 & 62 \\
South $(\mathrm{N}=126)$ & 17 & 32 & 13 \\
Total $(\mathrm{N}=293)$ & 23 & 30 & 19 \\
\hline
\end{tabular}

Notes: In the original dataset, the trustee restrictions of a governing board is set of dichotomous variables indicating whether a governing board has requirements on trustees' political affiliation, residence, and alumni status. 
Table 4. Descriptive Information of Term

\begin{tabular}{|c|c|c|c|c|}
\hline Group & Length (years) & & $\begin{array}{l}\text { Term Limit } \\
\text { (Frequency of } \\
\text { Answering } \\
\text { "Yes") }\end{array}$ & $\begin{array}{c}\text { Removal } \\
\text { Process } \\
\text { (Frequency of } \\
\text { Answering } \\
\text { "Yes") }\end{array}$ \\
\hline \multicolumn{5}{|l|}{ West } \\
\hline Minimum & 4 & Yes (1) & 5 & 20 \\
\hline Maximum & 12 & No $(0)$ & 41 & 26 \\
\hline Average(mean) & 5.3 & Average(mean) & 0.1 & 0.4 \\
\hline \multicolumn{5}{|l|}{ Middle West } \\
\hline Minimum & 3 & Yes (1) & 15 & 8 \\
\hline Maximum & 9 & No $(0)$ & 51 & 58 \\
\hline Average(mean) & 6.7 & Average(mean) & 0.2 & 0.1 \\
\hline \multicolumn{5}{|l|}{ Northeast } \\
\hline Minimum & 3 & Yes (1) & 16 & 27 \\
\hline Maximum & 7 & No $(0)$ & 39 & 28 \\
\hline Average(mean) & 5.4 & Average(mean) & 0.3 & 0.5 \\
\hline \multicolumn{5}{|l|}{ South } \\
\hline Minimum & 3 & Yes (1) & 59 & 67 \\
\hline Maximum & 12 & No $(0)$ & 67 & 59 \\
\hline Average(mean) & 5.5 & Average(mean) & 0.5 & 0.5 \\
\hline
\end{tabular}

Table 5. ANOVA-test Results of Trustee Restriction by Region

\begin{tabular}{llrrrrr}
\hline & & Sum of & & \multicolumn{2}{c}{ Mean } \\
Variables & Group & Squares & df & Square & F & Sig. \\
\hline Political & Between Groups & 5.568 & 3 & 1.856 & 11.771 & 0.000 \\
Affiliation & Within Groups & 45.565 & 289 & 0.158 & & \\
& Total & 51.133 & 292 & & & \\
Regional & Between Groups & 2.103 & 3 & 0.701 & 3.706 & 0.012 \\
Requirement & Within Groups & 54.662 & 289 & 0.189 & & \\
& Total & 56.765 & 292 & & & \\
State & Between Groups & 9.327 & 3 & 3.109 & 16.171 & 0.000 \\
Alumni & Within Groups & 55.561 & 289 & 0.192 & & \\
& Total & 64.887 & 292 & & & \\
& Between Groups & 12.747 & 3 & 4.249 & 37.727 & 0.000 \\
& Within Groups & 32.55 & 289 & 0.113 & & \\
\hline
\end{tabular}


Public Higher Education Governing Boards Composition and Regional Difference in U.S.

Table 6. Post-Hoc Test (Sheffe) of Trustee Restriction

\begin{tabular}{lllrrr}
\hline \multicolumn{1}{c}{ Variable } & (I) region & (J) region & $\begin{array}{c}\text { Mean } \\
\text { Difference(I-J) }\end{array}$ & Std. Error & \multicolumn{1}{c}{ Sig. } \\
\hline Political & West & Northeast & $.395^{* * *}$ & 0.079 & 0.000 \\
Affiliation & & South & $.238^{* *}$ & 0.068 & 0.008 \\
& Middle & Northeast & $.345^{* * *}$ & 0.072 & 0.000 \\
& West & South & $.189^{*}$ & 0.06 & 0.022 \\
Regional & Northeast & Middle West & $-.227^{* *}$ & 0.079 & 0.044 \\
Requirement & & South & $-.219^{*}$ & 0.07 & 0.023 \\
State & Middle & West & $.404^{* * *}$ & 0.084 & 0.000 \\
Residence & West & Northeast & $.530^{* * *}$ & 0.08 & 0.000 \\
& & South & $.296^{* * *}$ & 0.067 & 0.000 \\
& \multirow{3}{*}{ Northeast } & South & $-.234^{*}$ & 0.071 & 0.013 \\
& Northeast & West & $.596^{* * *}$ & 0.067 & 0.000 \\
& & Middle West & $.542^{* * *}$ & 0.061 & 0.000 \\
& & South & $.491^{* * *}$ & 0.054 & 0.000 \\
\hline
\end{tabular}

Table 7. ANOVA-test Results of Trustee's Term by Region

\begin{tabular}{llrrrrr}
\hline \multirow{2}{*}{ Variables } & \multicolumn{1}{c}{ Group } & $\begin{array}{r}\text { Sum of } \\
\text { Squares }\end{array}$ & df & $\begin{array}{c}\text { Mean } \\
\text { Square }\end{array}$ & F & Sig. \\
\hline Length & Between Groups & 81.286 & 3 & 27.095 & $9.468^{* * *}$ & 0.000 \\
& Within Groups & 827.055 & 289 & 2.862 & & \\
& Total & 908.341 & 292 & & & \\
Term Limit & Between Groups & 5.432 & 3 & 1.811 & $8.905 * * *$ & 0.000 \\
& Within Groups & 58.766 & 289 & 0.203 & & \\
Removal & Total & 64.198 & 292 & & & \\
Process & Between Groups & 7.748 & 3 & 2.583 & $11.763 * * *$ & 0.000 \\
& Within Groups & 63.453 & 289 & 0.22 & & \\
& Total & 71.201 & 292 & & & \\
\hline
\end{tabular}

Table 8. Post-Hoc Test (Sheffe) of Trustee's Term

\begin{tabular}{lllrrr}
\hline Variable & \multirow{2}{*}{$(\mathrm{I})$ region } & \multicolumn{1}{c}{$(\mathrm{J})$ region } & $\begin{array}{c}\text { Mean } \\
\text { Difference(I-J) }\end{array}$ & $\begin{array}{c}\text { Std. } \\
\text { Error }\end{array}$ & \multicolumn{1}{c}{ Sig. } \\
\hline Length & MW & West & $1.356^{* *}$ & 0.325 & 0.001 \\
& & Northeast & $1.282^{* *}$ & 0.309 & 0.001 \\
& & South & $1.206^{* * *}$ & 0.257 & 0.000 \\
Limit & \multirow{3}{*}{ South } & West & $.360^{* * *}$ & 0.078 & 0.000 \\
\multirow{2}{*}{ Removal } & \multirow{2}{*}{ Middle West } & Middle West & $.241^{* *}$ & 0.069 & 0.007 \\
Process & & West & $-.314^{*}$ & 0.09 & 0.008 \\
& & Northeast & $-.370^{*}$ & 0.086 & 0.000 \\
& & South & $-.411^{*}$ & 0.071 & 0.000 \\
\hline
\end{tabular}

